\title{
The Adsorptive Properties of Fired Clay Pellets for the Removal of Phosphate in Wastewater Treatment
}

\author{
[ Uduakobong A. Edet, Mark J. Bateman, Augustine O. Ifelebuegu, Adrian Wood]
}

\begin{abstract}
Removal of phosphate in wastewater treatment is crucial to reducing nutrient enrichment and eutrophication of aquatic bodies. This study explored the potential of fired clay pellets for use in phosphate removal during wastewater treatment. The mechanism of removal was evaluated in a batch adsorption study under different experimental conditions. Fired clay pellets were found to be effective in the adsorptive removal of phosphate from aqueous solution with a maximum adsorption capacity of $144 \mathrm{mg} / \mathrm{g}$. The experimental data showed a good fit to the pseudo-first-order kinetic model indicating a physical nature of the sorption process and also followed Dubinin-Radushkeivich Isotherm model. Adsorption of phosphate favoured acidic $\mathbf{p H}$ with optimum removal at pH 34. The values of Gibbs free energy $(-16.5 \mathrm{~kJ} / \mathrm{mol})$, enthalpy ($8.87 \mathrm{~kJ} / \mathrm{mol}$ ) indicated adsorption was spontaneous and exothermic. The mechanism was found to be predominantly physisorption supported by some diffusion.
\end{abstract}

Keywords—adsorption, kinetics, phosphate, clay, isotherm

\section{Introduction}

Excessive or elevated nutrients in the water system may enhance the increase in plant based organic matter hence causing eutrophication and algal blooms [1,2,3,4,5]. Phosphate has been cited as a vital and limiting nutrient in freshwater system and has been suggested that a decrease in phosphate can effectively control eutrophication in coastal and fresh water systems $[2,6,7]$. Phosphates in wastewater may originate from industrial use of phosphate as a raw material, domestic use of phosphate-containing detergents and runoff from application of phosphate fertilizers to agricultural lands [8]. As eutrophication is a major issue, the effective and efficient removal of phosphate during wastewater treatment is crucial. The Urban Waste Water Treatment Directive mandates an $80 \%$ reduction in phosphorus level or an effluent $\mathrm{P}$ concentration of $2 \mathrm{mg} / \mathrm{L} \mathrm{P}$ for $10,000-100,000$ p.e and $1 \mathrm{mg} / \mathrm{L}$ for population estimate greater than 100,000 . This directive has led to a decreasing low level of $\mathrm{P}$ in wastewater effluent during treatment through increased government regulatory pressure [1].

Several methods of phosphate removal have been employed in wastewater treatment. These include chemical precipitation involving the addition of calcium, iron and aluminium salts. This is the commonly used and the most effective method of phosphate removal in wastewater treatment plant (WWTP),

Uduakobong A. Edet, Mark J. Bateman, Augustine O. Ifelebuegu, Adrian Wood

Coventry University

United Kingdom and often resulting in high phosphate removal levels $[9,10]$. The major drawbacks of the method are the high volume of sludge produced [11] and the cost of chemicals required for dosing [12]. Biological phosphate removal has also been used in wastewater treatment $[13,14,15]$ and it depends on a combination of factors such as $\mathrm{pH}$ and temperature for effective performance [16,17]. Consequently, it has a variable and inconsistent removal rate which may require a complimentary treatment to produce low phosphate effluent levels $[18,19]$.

Adsorption of phosphate to suitable materials is becoming a frequently used method of removing phosphate in wastewater treatment. This could be attributed to its advantages over chemical precipitation and biological $\mathrm{P}$ removal. These advantages include low cost, capacity to produce re-usable solid, the simplicity make this method a favourable option in wastewater treatment $[16,20]$. Fe, Al and $\mathrm{Ca}$ are the elements that are often credited with phosphate sorption and it is assumed that if these elements are present in any medium in a substantial amount, then that medium can be used for phosphate removal [21].

Several studies have been conducted using various low cost adsorbents such as: alunite [22,23], fly ash [24,25], opoka [26,27,28], Polonite [29], sand [30,31], Lightweight aggregate (LWA)/Light Expanded Clay aggregate (LECA) $[32,33,34]$, ochre [35], red mud [36], and clay [8,37] for the removal of phosphate from wastewater. The studies have been carried out in a laboratory, small scale constructed wetland or a full scale constructed wetland with the adsorbents used as filter media [30].

Clay has been studied as a low cost adsorbent in the removal of phosphate from wastewater and different phosphate removal rates has been recorded. In a phosphate removal studies done with raw and acid treated clay from Malawi, a high brick dosage of $60 \mathrm{~g} / \mathrm{L}$ was required for a removal rate of $80 \%$ using the acid treated clay while the raw clay only achieved a maximum removal rate of $60 \%$ and was believed that different phosphate removal mechanisms were responsible for phosphate removal at different $\mathrm{pH}$ [8]. At a low $\mathrm{pH}$, it was believed that the removal was through phosphate adsorption to iron oxide, while the phosphates were precipitated out by calcium ions at a higher $\mathrm{pH}$ [8].

The use of fired clay for removal of pollutants in wastewater treatment has been reported [38,39,40,41]. This work explored the feasibility of employing fired clay pellets for the removal of phosphate from wastewater. The phosphate adsorptive properties (calcination temperature of the pellets, $\mathrm{pH}$, sorption kinetics, isotherm and thermodynamics) were investigated in batch experiments. 


\section{Materials and Method}

\section{A. Preparation of Clay Pellets}

The clay used in this study was obtained from a clay pit in Marks Tey-Essex, United Kingdom. Deionised water was added to the clay to improve its handling. The clay was spread on to a metal grid measuring $1 \mathrm{~cm} \mathrm{x} 1 \mathrm{~cm} \times 1.5 \mathrm{~mm}$ which served as a mould for the pellets and left to air dry for two days. The pellets were fired in a Lenton Thermal Design General purpose chamber furnace ECF/12/22 at temperature from $540{ }^{\circ} \mathrm{C}$ to $1050{ }^{\circ} \mathrm{C}$

\section{B. Batch Adsorption Studies}

Anhydrous potassium dihydrogen phosphate $\left(\mathrm{KH}_{2} \mathrm{PO}_{4}\right)$ was used as the source of phosphate in this study. All reagents used were analytical grade and were obtained from Fisher Scientific of Sigma Aldrich UK.

$100 \mathrm{mg} / \mathrm{l}$ stock phosphate solution was prepared by dissolving $0.4393 \mathrm{~g}$ of $\mathrm{KH}_{2} \mathrm{PO}_{4}$ in $1000 \mathrm{ml}$ of deionised water. Phosphate solution used in the adsorption experiment was obtained by diluting appropriate volume of stock phosphate solution in deionised water.

Adsorption of phosphate was carried out by typically adding $3 \mathrm{~g}$ of calcined clay tiles to $150 \mathrm{ml}$ of $50 \mathrm{mg} / \mathrm{l}$ phosphate solution in a stoppered Erlenmeyer flask and stirring in an orbital shaker at $170 \mathrm{rpm}$ for 120 minutes. Aliquots were drawn at regular intervals, filtered before analysis using FOSS FIAstar 5000 analyzer. Adsorbed phosphate was calculated as the difference in the concentration of phosphate added and the phosphate concentration remaining in the equilibrating solution. All experiments were carried in triplicates. The rate of phosphate adsorption was calculated as:

$$
\text { Phosphate removal }(\%)=\underline{\mathrm{C}_{\mathrm{o}}}-\mathrm{C}_{\mathrm{t}} \times 100
$$

Where $\mathrm{C}_{\mathrm{o}}$ is initial phosphate concentration and $\mathrm{C}_{\mathrm{t}}$ is phosphate concentration at time $t$

The equilibrium adsorption capacity (qe) was calculated using the equation:

$$
\mathrm{qe}=\frac{\left(\mathrm{C}_{\underline{0}}-\mathrm{Ce}\right) \times \mathrm{V}}{\mathrm{m}}
$$

Where $\mathrm{C}_{\mathrm{o}}$ and $\mathrm{C}_{\mathrm{e}}$ is the initial and equilibrium phosphate concentration respectively $(\mathrm{mg} / \mathrm{l}), \mathrm{V}$ is the volume of phosphate solution (l) and $\mathrm{m}$ is the mass of clay pellets.

The point of zero charge $\left(\mathrm{pH}_{\mathrm{zpc}}\right)$ of the sample was determined using a procedure previously described. [42,43].

To investigate the effect of $\mathrm{pH}$ on the adsorption of phosphate, $3 \mathrm{~g}$ of calcined clay pellets was added to $150 \mathrm{ml}$ of $50 \mathrm{mg} / \mathrm{L}$ phosphate of different initial $\mathrm{pH}$ ranging from 2.0 to 12.0 adjusted by adding $0.10 \mathrm{M} \mathrm{HCl}$ or $\mathrm{NaOH}$. Similar mass of clay pellets and concentration of phosphate solution was used to study the effect of phosphate at different temperature. The effect of initial concentration was investigated by adding $5 \mathrm{~g}$ of calcined clay pellets to $200 \mathrm{ml}$ of phosphate solution containing varying initial concentration.
The experimental data obtained from the study were analysed using various kinetic models: Lagergren pseudofirst order, pseudo second order, Intraparticle, Elovich and Bangham's kinetic models. Thermodynamic parameters including Gibbs free energy, entropy and enthalpy were also investigated. The adsorption isotherm was also investigated using Langmuir, Freundlich, Tempkin and DubininRadushkeivich isotherm models.

\section{Results and Discussion}

\section{A. Effect of Firing Temperature}

The effect of firing temperature of clay pellets on the adsorption of phosphate was studied using $3 \mathrm{~g}$ clay pellets fired at temperature from $540{ }^{\circ} \mathrm{C}$ to $1050{ }^{\circ} \mathrm{C}$ and $150 \mathrm{ml}$ of $50 \mathrm{mg} / \mathrm{l}$ phosphate solution. The results are illustrated in Fig 1 .

It can be observed from Fig. 2 phosphate adsorption was enhanced with increase in firing temperature as the temperature increased from $540{ }^{\circ} \mathrm{C}$ to $960{ }^{\circ} \mathrm{C}$ before declining. Phosphate adsorption reached a maximum when the clay pellets were fired at $850{ }^{\circ} \mathrm{C}$. Phosphate sorption declined slightly when the firing temperature was between $900{ }^{\circ} \mathrm{C}$ and $1000{ }^{\circ} \mathrm{C}$. There has been limited research on the effect of firing temperature of clay for use as an adsorbent in water and wastewater treatment. A pivotal study in this area was the study on defluoridation of drinking water which showed fluoride adsorption decreased with increasing firing temperature [38]. Flouride adsorption using clay fired at $600^{\circ} \mathrm{C}$ was found to be most effective, while those fired above $700^{\circ} \mathrm{C}$ and above showed a decreased fluoride adsorption $[38,39,40]$. Another study on the removal of $\mathrm{Cr}(\mathrm{VI})$ using fired brick clay showed a decrease in the removal of $\mathrm{Cr}(\mathrm{VI})$ when firing temperature increased from $200^{\circ} \mathrm{C}$ to $600^{\circ} \mathrm{C}$ [41]. These findings are contrary to results obtained in this study.

Firing of clay generally reduces water trapped between the silicate sheets of the clay producing hard granules that, even when fully saturated with water, do not disintegrate easily [46]. During fluid bed drying, which is the first stage of firing, occurring between $120^{\circ} \mathrm{C}$ and $174^{\circ} \mathrm{C}$, moisture content is reduced to $6 \%-9 \%$ from $40 \%-45 \%$ and further moisture reduction is achieved up to $0 \%$ in some cases, when the temperature is between $460^{\circ} \mathrm{C}$ and $800^{\circ} \mathrm{C}$. Sorption properties of clay are enhanced during firing as a result of the aggregation of clay particles creating a stable porous internal structure [46]. Although firing may reduce the exchange capacity of the clay, internal pores and surface binding can ensure the retention of the sorption properties. Heat treatment has been shown to cause the collapse of the interlayer in 2:1 Ca-montmorillonite 


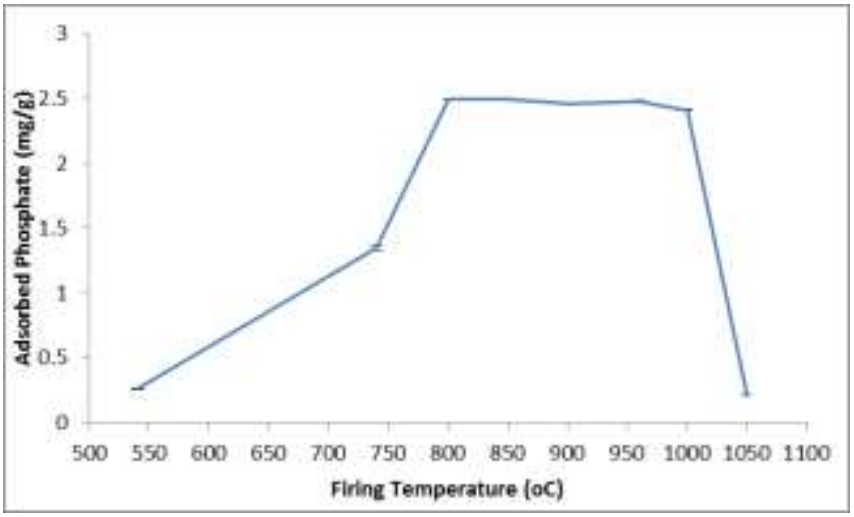

Figure 1. Effect of calcination temperature on adsorption of phosphate by calcined clay pellets $(n=3)$

through the incorporation of cations into the tetrahedral or unoccupied octahedral sheets when the calcination temperature was between $200^{\circ} \mathrm{C}$ and $400^{\circ} \mathrm{C}$ [47]. The physiochemical properties such as micromesopore volume, specific area and total surface acidity generally decrease with increasing temperature when the temperature exceeds $450^{\circ} \mathrm{C}$. Acidic binding has been shown to increase with increasing temperature particularly at the regions of dehydration and dehydroxylation $100^{\circ} \mathrm{C}$ to $500^{\circ} \mathrm{C}$ and $550^{\circ} \mathrm{C}$ to $700^{\circ} \mathrm{C}$ respectively [48].

Decomposition of the silicate layer in the clay sheets and the collapse of the mesopore and micropore due to inter- and intraparticle sintering occurs when the temperature is increased causing a rapid decline in the specific surface area and specific micromesopore volume [48] This is believed to cause the sudden decline in the adsorption of phosphate using clay tiles fired at $1050^{\circ} \mathrm{C}$ seen in this study.

\section{B. Effect of Mass of Adsorbent}

The effect of the mass of clay pellets was investigated for phosphate adsorption with other experimental condition left constant $\left(150 \mathrm{ml}\right.$ of $50 \mathrm{mg} / \mathrm{l}$ phosphate; temperature $20{ }^{\circ} \mathrm{C} \pm$ $2{ }^{\circ} \mathrm{C}$; pH 7) The adsorption of phosphate was shown to increase with an increase in mass of clay pellets (Fig 2), however, there was no change in the adsorption of phosphates between $3 \mathrm{~g}$ and $5 \mathrm{~g}$ pellets. This could be attributed to the overlapping of active reaction sites as the mass of tile increased [49]. The increase in phosphate adsorption is due to a greater surface area and consequently increased available binding sites when the adsorbent dose increases [50,51].

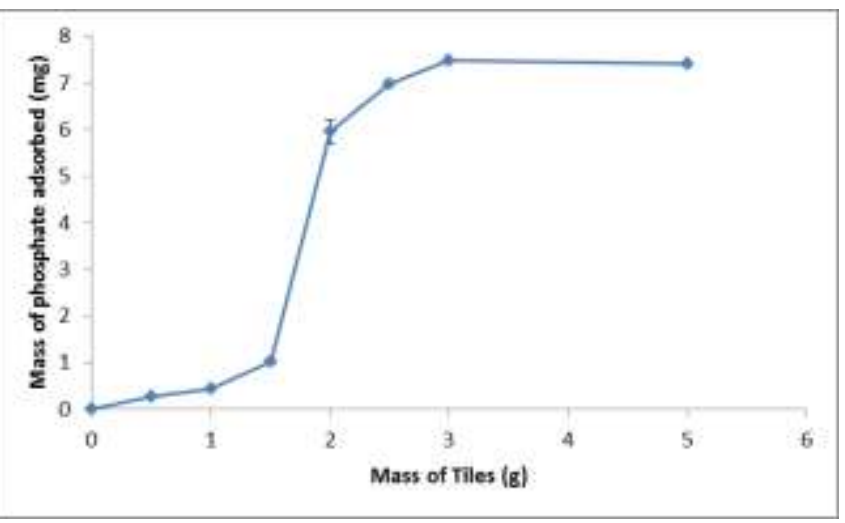

Figure 2: Effect of mass of adsorbent on the adsorption of phosphate

\section{Effect of $p H$}

The effect of $\mathrm{pH}$ on phosphate adsorption was studied at $\mathrm{pH}$ between 2 and 12. It was observed that phosphate adsorption increased sharply when $\mathrm{pH}$ increased from 2 to 3 , followed by a slight decline as $\mathrm{pH}$ increased to 12 (Fig. 3). The highest level of phosphate adsorption was achieved at $\mathrm{pH} 4$. The results obtained were consistent with other studies on the mechanism for the adsorption of phosphate onto solid waste [52]. Phosphate adsorption with other water-adsorbent interfaces is strongly dependent on $\mathrm{pH}$ [53]. The general trend reported for the effect of $\mathrm{pH}$ on phosphate adsorption follows the pattern described in Fig. 3, however, it is suggested that phosphate adsorption occur can occur within two $\mathrm{pH}$ ranges [8] although phosphate adsorption across three $\mathrm{pH}$ ranges have also been known to occur [54,55]. Phosphate adsorption using red mud was reported to decrease with increase in $\mathrm{pH}$, due to the alkaline properties of red mud at low $\mathrm{pH}$ resulting in greater adsorption of acidic ions [36]. This contradicts the results of this study as 91\% removal was obtained at $\mathrm{pH} 12$.

Clay predominantly contains oxides of metals such as $\mathrm{Ca}, \mathrm{Fe}$ and $\mathrm{Al}$; and nonmetals such as $\mathrm{Si}$. These oxides play a role in phosphate adsorption as they are hydroxylated when in contact with water and positive or negative charged developed on the interface depending on the $\mathrm{pH}$ [56]. The positive charged interface serves as bonding sites for phosphates adsorption. Surface charges on the pellets are produced as a result of the hydrolysis of the $\mathrm{Si}-\mathrm{OH}$ or Al$\mathrm{OH}$ bonds along the clay lattice [57]. These charges could be positively and negatively charged, depending on the $\mathrm{pH}$ and structure of the silica. The zero point charge $\left(\mathrm{pH}_{\mathrm{zpc}}\right)$ of the clay pellets was 8.13 and is within the range reported for smectite which is the predominant mineral found in the clay $[58,59]$. When the $\mathrm{pH}$ is less than $\mathrm{pH}_{\mathrm{zpc}}$ the clay surface has a net positive charge and the propensity to attract anions increases. When $\mathrm{pH}$ is greater than $\mathrm{pH}_{\mathrm{zpc}}$ the clay surface is negatively charged and the attraction of anions decreases. Phosphate adsorption in this study was found to be higher at $\mathrm{pH}$ lower than $\mathrm{pH}_{\mathrm{zpc}}$. This result is consistent with reports of other studies $[8,43]$. 


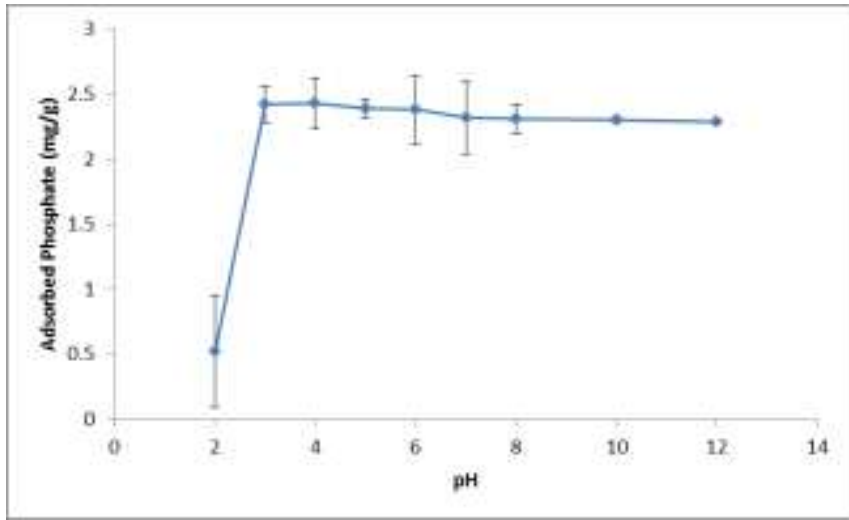

Figure 4: Phosphate adsorption at diffenet $\mathrm{pH}$

\section{Adsorption Kinetics}

Adsorption kinetics is one of the most crucial factors in the design of adsorption During the design and optimization of full scale applications, adsorption kinetics is essential in choosing optimum operating conditions and examining potential rate controlling mechanism [60,61]. Adsorption mechanism of phosphate from aqueous solution was investigated using various kinetic models; pseudo first order, pseudo second order, Elovich, and Bangham's kinetic models were used in this study.

Pseudo first order kinetics model explains the relationship between the occupation of adsorption sites and the number of occupied sites on the adsorbent. It is defined using Lagergren equation $[62,63]$

$$
\operatorname{Ln}\left(\mathrm{C}_{\mathrm{t}} / \mathrm{C}_{\mathrm{o}}\right)=-\mathrm{kt}
$$

where $\mathrm{C}_{\mathrm{o}}$ and $\mathrm{C}_{\mathrm{t}}$ is the initial concentration of the adsorbate and $\mathrm{C}_{\mathrm{o}}$ is adsorbate concentration at time $\mathrm{t}(\mathrm{mg} / \mathrm{l})$ respectively, $\mathrm{k}_{1}$ is the equilibrium rate constant $\left(\mathrm{min}^{-1}\right)$. A plot of $\ln \left(\mathrm{C}_{\mathrm{t}} / \mathrm{C}_{\mathrm{o}}\right)$ against $\mathrm{t}$ should yield a linear relationship and $\mathrm{k}_{1}$ determined from the slope.

Pseudo second order kinetic is used to describe the dependency of the adsorption capacity of the adsorbent on time. It is calculated using equilibrium adsorption capacity as is expressed as

$$
1 /\left[\mathrm{C}_{\mathrm{t}}\right]-1 /\left[\mathrm{C}_{\mathrm{o}}\right]=\mathrm{kt}
$$

where $\mathrm{k}_{2} \mathrm{q}_{\mathrm{e}}{ }^{2}$ is the initial adsorption rate when $\mathrm{t} \rightarrow 0$ and $\mathrm{k}_{2}$ is the pseudo second order rate constant $(\mathrm{g} / \mathrm{mg} / \mathrm{min})$. A plot of the $1 / C_{t}-1 / C_{o}$ against time is used to determine $k_{2}$.

Elovich kinetic model was initially used to describe chemisorption of gases onto heterogeneous surface and is now used to study removal of pollutants from aqueous solution. It describes second order kinetics with the assumption that the solid surface has heterogeneous energy [64]. The Elovich model is represented as

$$
\frac{d q}{d t .}=\mathrm{a}^{-\alpha q}
$$

Where $\mathrm{q}$ is the amount of adsorbate adsorbed at time $\mathrm{t}$; $\mathrm{a}$ is the adsorption constant and $\alpha$ is the initial rate of adsorption (g/g/min). Integrating Equation (5) assuming the boundary conditions of $\mathrm{q}=0$ at $\mathrm{t}=0$ and $\mathrm{q}=\mathrm{q}$ at $\mathrm{t}=\mathrm{t}$ yields

$$
\mathrm{q}=\alpha \ln (\mathrm{a} \alpha)+\alpha \ln \mathrm{t}
$$

The linear form is expressed as

$$
\mathrm{qt}=\frac{\ln \alpha b}{b}+\frac{1}{b} \ln t
$$

where $b$ is related to the extent of surface coverage and activation energy for chemisorption. A plot of $q_{t}$ against $\ln t$ yields a straight line and $\alpha$ and $b$ determined from the slope and intercept respectively.

Bangham's kinetic model is used to evaluate the dominace of pore diffusion in the adsorption process [65]. It is expressed as:

$\log \log \left[\mathrm{C}_{\mathrm{o}} /\left(\mathrm{C}_{\mathrm{o}}-\mathrm{qtM}\right)\right]=\log \left[\mathrm{k}_{\mathrm{o}} / 2.303 \mathrm{~V}\right]+\alpha \log \mathrm{t}$

Where $\mathrm{C}_{\mathrm{o}}$ is the initial concentration of adsorbate $(\mathrm{mg} / \mathrm{l})$, $\mathrm{V}$ is the volume of the solution $(\mathrm{ml}), \mathrm{M}$ is the mass of adsorbent $(\mathrm{g} / \mathrm{l}) \mathrm{qt}$ is the amount of adsorbate adsorbent at time $\mathrm{t}$ and $\mathrm{k}_{\mathrm{o}}$ and $\alpha$ are constant. The plot of $\log \log$ $\left[\mathrm{C}_{\mathrm{o}} /\left(\mathrm{C}_{\mathrm{o}}-\mathrm{qtM}\right)\right]$ against $\log \mathrm{t}$ is used to determine $\mathrm{k}_{\mathrm{o}}$ and $\alpha$ from the slope and intercept. Table 1 shows the results obtained for pseudo first order, pseudo second order, Elovich and Bamgham's kinetic model for phosphate.

Table 1 presents kinetic parameters of the sorption of phosphate onto clay pellets. The kinetic plot showed good fit of sorption equilibrium data for pseudo first order model suggesting physisorption was the rate controlling

\section{E. Intra-particle Diffusion Kinetics}

The adsorption mechanism of solute onto adsorbent can be described using the intra particle diffusion kinetic model expressed as [61]:

$$
\mathrm{q}_{\mathrm{t}}=\mathrm{K}_{\mathrm{di}} \sqrt{t}+\mathrm{C}_{\mathrm{i}}
$$

where $K_{\text {dif }}$ is the intra particle rate constant $\left(\mathrm{mg} \mathrm{g}^{-}\right.$ ${ }^{1}$ mins ${ }^{0.5}$ ). A plot of $\mathrm{q}_{\mathrm{t}}$ against the square root of time should be linear and the line passing through the origin if intra particle diffusion is the rate controlling step. The plot showed a poor fit $\left(\mathrm{R}^{2}=0.78\right)$ and a multi-linear profile that do not pass through the origin (Fig. 5). The profile shows a multi-step process, where the initial section may be considered as an area of fast uptake as a result of the boundary layer diffusion on the surface of the pellet and the middle section is the stage limited by intra particle diffusion [66].

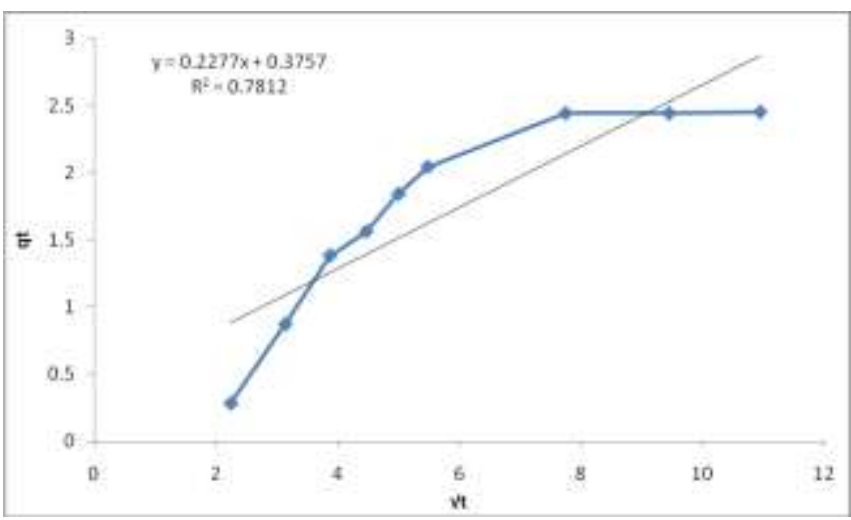

Figure 5: Intra particle kinetic model plot for phosphate. 
Proc. of the Fourth Intl. Conf. Advances in Bio-Informatics, Bio-Technology and Environmental Engineering- ABBE 2016

Copyright (C) Institute of Research Engineers and Doctors, USA .All rights reserved.

ISBN: 978-1-63248-091-0 doi: 10.15224/ 978-1-63248-091-0-05

The last stage is shows a decreasing adsorption due to low residual phosphate concentration in the solution $[61,66]$.

\section{F. Adsorption Isotherms}

Adsorption isotherms help to model design parameters and to understand the distribution of adsorbate between the aqueous and solid phase [61]. The equilibrium data was analyzed using Langmuir, Freundlich, Tempkin, and Dubinin- Radushkeivich isotherm models. The Langmuir, Freundlich, Tempkin, and Dubinin- Radushkeivich (D-R) isotherm models are represented by Equations (10) to (13) respectively [ ]:

$$
\begin{gathered}
\mathrm{q}_{\mathrm{e}}=\mathrm{Q}_{\mathrm{m}} \mathrm{K}_{\mathrm{L}} \mathrm{C}_{\mathrm{e}} / 1+\mathrm{K}_{\mathrm{L}} \mathrm{C}_{\mathrm{e}} \\
\mathrm{Q}_{\mathrm{e}}=\mathrm{K}_{\mathrm{f}} \mathrm{C}_{\mathrm{e}}^{1 / \mathrm{n}} \\
\mathrm{q}_{\mathrm{e}}=B \ln A_{T}+B \ln C_{e} \\
\ln \mathrm{q}_{\mathrm{e}}=\ln \mathrm{q}_{\mathrm{s}-} \beta \varepsilon^{2} \\
\text { where } \varepsilon=\mathrm{RT} \ln \left(1+1 / \mathrm{C}_{\mathrm{e}}\right)
\end{gathered}
$$

where $\mathrm{Q}_{\mathrm{m}}$ is the maximum monolayer adsorption capacity $(\mathrm{mg} / \mathrm{g}), \mathrm{K}_{\mathrm{L}}$ is Langmuir adsorption constant $(\mathrm{L} / \mathrm{mg}), \mathrm{n}$ is adsorption intensity, $\mathrm{K}_{\mathrm{f}}$ is the Freundlich isotherm constant, $A_{T}$ is Tempkin isothern equilibrium binding constant $(\mathrm{L} / \mathrm{g}), \mathrm{B}$ is constant related to heat of sorption $(\mathrm{J} / \mathrm{mol})$ and $\mathrm{R}$ is universal gas constant $(8.314$ $\mathrm{J} / \mathrm{mol} / \mathrm{K}$ ). Table 2 represents adsorption isotherms coefficients for single solute adsorption isotherms and their correlation coefficients after analyzing linear plots of Equations (9) to (12). The data obtained showed a better fit for the D-R isotherm model, the E value was $2.87 \mathrm{~kJ} / \mathrm{mol}$ indicating the adsorption was a physical process as $\mathrm{E}$ value $<8 \mathrm{~kJ} / \mathrm{mol}$ is classified as physical adsorption. $\mathrm{Q}_{\mathrm{m}}$ value of $144.93 \mathrm{mg} / \mathrm{g}$ implies a significant potential for phosphate removal from wastewater at an industrial scale using fired

\begin{tabular}{|c|c|c|}
\hline Kinetic Model & Parameter & \\
\hline \multirow{2}{*}{ Pseudo first order } & $K_{1}(/ \min )$ & 0.03 \\
\hline & $\mathbf{R}^{2}$ & 0.9932 \\
\hline \multirow{3}{*}{$\begin{array}{l}\text { Pseudo second } \\
\text { order }\end{array}$} & $K_{2}(g / m g / m i n)$ & 0.02 \\
\hline & h (mg/g/min) & 8.8 \\
\hline & $\mathbf{R}^{2}$ & 0.6506 \\
\hline \multirow{3}{*}{ Elovich } & $\alpha(\mathrm{mg} / \mathrm{g} / \mathrm{min})$ & 0.32 \\
\hline & $b(\mathrm{~g} / \mathrm{mg})$ & 1.10 \\
\hline & $\mathbf{R}^{2}$ & 0.9872 \\
\hline \multirow{3}{*}{ Bangham's } & $\mathrm{K}_{\mathbf{0}}(\mathrm{ml} / \mathrm{g} / \mathrm{l})$ & 0.41 \\
\hline & $\alpha$ & 0.11 \\
\hline & $\mathbf{R}^{2}$ & 0.9755 \\
\hline
\end{tabular}
clay pellets and is similar to result obtained in previous study [42].

Table 1. Kinetic models adsorption parameters for

\begin{tabular}{|c|c|c|}
\hline $\begin{array}{c}\text { Adsorption } \\
\text { Isotherm Model }\end{array}$ & Parameter & \\
\hline \multirow{4}{*}{ Langmuir } & $\mathbf{Q}_{\mathrm{m}}$ & 144.93 \\
\hline & $\mathbf{K}_{\mathrm{L}}$ & 0.09 \\
\hline & $\mathbf{R}_{\mathrm{L}}$ & 0.02 \\
\hline & $\mathbf{R}^{2}$ & 0.9096 \\
\hline \multirow{4}{*}{ Freundlich } & $\mathbf{K}_{\mathbf{f}}$ & 6.50 \\
\hline & $1 / n$ & 0.26 \\
\hline & $\mathbf{n}$ & 3.84 \\
\hline & $\mathbf{R}^{2}$ & .5688 \\
\hline \multirow{4}{*}{ Tempkin } & $\mathbf{A}_{\mathrm{T}}$ & 1.08 \\
\hline & $b$ & 68.50 \\
\hline & $B$ & 35.58 \\
\hline & $\mathbf{R}^{2}$ & 0.7989 \\
\hline \multirow{3}{*}{ D-R } & $\mathbf{K}_{\mathbf{a d}}$ & 0.06 \\
\hline & $\mathbf{E}$ & 2.87 \\
\hline & $\mathbf{R}^{2}$ & 0.9537 \\
\hline
\end{tabular}
calcined clay pellets
Table 2. Adsorption Isotherm constants for adsorption of phosphate onto fired clay pellets

\section{G. Effect of Temperature}

The effect of temperature on the adsorption of phosphate was investigated at temperatures of $20^{\circ} \mathrm{C}, 25^{\circ} \mathrm{C}, 30^{\circ} \mathrm{C}$ and $35^{\circ} \mathrm{C}$, while other conditions were kept constant. Phospahte adsorption was found to decrease with an increase in temperature. Thermodynamic parameters such as changes in Gibbs free energy $\left(\Delta \mathrm{G}^{\mathrm{o}}\right)$, enthalpy $\left(\Delta \mathrm{H}^{\mathrm{o}}\right)$ and entropy $\left(\Delta \mathrm{S}^{\mathrm{o}}\right)$ are used to determine the spontaneous nature of the adsorption process and evaluate the applicability of the adsorbent [68]. The parameters were determined using Equations (15) to (17):

$$
\begin{gathered}
\Delta \mathrm{G}^{\mathrm{o}}=-\mathrm{RT} \ln \mathrm{K}_{\mathrm{d}} \\
\Delta \mathrm{G}^{\mathrm{o}}=\left(\Delta \mathrm{H}^{\mathrm{o}}\right)-\mathrm{T}\left(\Delta \mathrm{S}^{\mathrm{o}}\right) \\
-\mathrm{RT} \ln \mathrm{K}_{\mathrm{d}}=\left(\Delta \mathrm{H}^{\mathrm{o}}\right)-\mathrm{T}\left(\Delta \mathrm{S}^{\mathrm{o}}\right)
\end{gathered}
$$

Where $\mathrm{R}$ is the universal gas constant, $\mathrm{T}$ is temperature in Kelvin $(\mathrm{K})$ and $\mathrm{K}_{\mathrm{d}}=\left(\mathrm{q}_{\mathrm{e}}-\mathrm{C}_{\mathrm{e}}\right)$ is the quantity of adsorbate adsorbed onto the adsorbent $(1 / \mathrm{g})$. The plot of $\ln \mathrm{K}_{\mathrm{d}}$ against $1 / \mathrm{T}$ yielded a straight line graph with $\Delta \mathrm{H}^{\circ}$ and $\Delta \mathrm{S}^{\circ}$ determined from the slope and intercept respectively. The thermodynamic parameters obtained from the graph are shown in Table 3. The Gibbs free energy obtained was -16.5 $\mathrm{kJ} / \mathrm{mol}$, the negative value indicates the spontaneous nature of the sorption process and the process was thermodynamically favourable. The value of $\Delta \mathrm{G}^{\mathrm{o}}$ suggests a physisorption process as values of $\Delta \mathrm{G}^{\circ}$ between $-20 \mathrm{~kJ} / \mathrm{mol}$ and $0 \mathrm{~kJ} / \mathrm{mol}$ are classified as physisorption. The negative value of of the enthalpy $(-8.87 \mathrm{~kJ} / \mathrm{mol})$ confirms the exothermic nature of the process and the positive entropy 
Proc. of the Fourth Intl. Conf. Advances in Bio-Informatics, Bio-Technology and Environmental Engineering- ABBE 2016 Copyright (C) Institute of Research Engineers and Doctors, USA .All rights reserved.

ISBN: 978-1-63248-091-0 doi: 10.15224/ 978-1-63248-091-0-05

Table 3. Thermodynamic parameters for phosphate

\begin{tabular}{|l|l|}
\hline Parameter & Phosphate \\
\hline Gibbs free Energy (kJ/mol) & -16.5 \\
\hline Enthalpy (kJ/mol) & -8.87 \\
\hline Entropy (kJ/mol) & 0.026 \\
\hline
\end{tabular}

value $(0.026 \mathrm{~kJ} / \mathrm{mol})$ indicates an increased randomness at the solid-solution interface and a good affinity of phosphate ions towards the clay pellets [68]

\section{H. Conclusion}

The adsorptive properties of fired clay for the removal of phosphate in wastewater treatment were investigated. The removal of phosphate was favoured at acidic $\mathrm{pH}$ with optimum removal at $\mathrm{pH} 3-4$. The adsorption of phosphate showed a good fit with pseudo first order kinetic model, which indicated the physical nature of the sorption process, and Dubinin-Radushkeivich Isotherm model. The Gibbs free energy was $-16.5 \mathrm{kJol} / \mathrm{mol}$, indicating the adsorption process was spontaneous. The enthalpy value for phosphate $(-8.87$ $\mathrm{kJ} / \mathrm{mol}$ ) confirmed the exothermic nature of the process. The thermodynamic and isotherm data obtained all supported the mechanism of adsorption of phosphate to be physisorption supported by some diffusion.

\section{Acknowledgment}

The authors will like to thank The Niger Delta Development Commission for their support.

\section{References}

[1] C. Vohla, M. Kõiv, H. J. Bavor, F. Chazarenc, and Ü Mander, "Filter materials for phosphorus removal from wastewater in treatment wetlands-A Review," in Ecological Engineering, vol. 37 No. 1, 2011, pp. 70-89.

[2] D. M. R. Mateus, and H. J. O. Pinho, "Phosphorus removal by expanded clay-six years of pilot-scale constructed wetlands experience" in Water Environment Research vol. 82 No. 2, 2010, pp. 128-137 .

[3] V. H. Smith, and D. W. Schindler, "Eutrophication Science: where do we go from here?," in Trends in Ecology \& Evolution vol. 24 No. 4, 2009, pp. 201-207.

[4] N. F. Y. Tam, Y. S. Wong, and M. H. Wong, "Novel technology in pollutant removal at source and bioremediation," in ocean and coastal management vol. 52 No.7, 2009, pp. 368-373.

[5] S. Wang, X. Jin, Y. Pang, H. Zhao, and X. Zhou, "The study of the effect of ph on phosphate sorption by different trophic lake sediments," in Journal of Colloid and Interface Science vol. 285 No. 2, 2005, 448-457.

[6] V. H. Smith, "Eutrophication of freshwater and coastal marine ecosystems: A global problem," in Environmental Science and Pollution Research vol. 10 No. 2, 2003, pp. 126-139.

[7] T. Tyrrell, "The relative influences of nitrogen and phosphorus on oceanic primary production," in Nature 400 . vol. 6744, 1999, pp 525-531.

[8] M. W. Kamiyango, W. R. L. Masamba, S. M. I. Sajidu, and E. Fabiano, "Phosphate removal from aqueous solutions using kaolinite obtained from Linthipe, Malawi," in Physics and Chemistry of the Earth vol. 34 No. 13-16, 2009, pp. 850-856.

[9] T. Clark, T. Stephenson, and P. A. Pearce, "Phosphorus removal by chemical precipitation in a biological aerated filter," in Water Research vol. 31 No. 10, 1997, pp. 2557-2563.
[10] J. M. Ebeling, P. L. Sibrell, S. R. Ogden, and S. T. Summerfelt, "Evaluation of chemical coagulation-flocculation aids for the removal of suspended solids and phosphorus from intensive recirculating aquaculture effluent discharge," in Aquacultural Engineering vol. 29 No. 1, 2003, pp. 23-42.

[11] S. Hussain, H. A. Aziz, M. H. Isa, A. Ahmad, J. Van Leeuwen, L. Zou, S. Beecham, and M. Umar, "Orthophosphate removal from domestic wastewater using limestone and granular activated carbon," in Desalination vol. 271 No.1, 2011, pp. 265-272.

[12] S. Kahraman, P. Yalcin, and H. Kahraman, "The evaluation of low cost biosorbents for removal of an azo dye from aqueous solution," in Water and Environment Journal 26 No.3, 2012, pp. 399-404.

[13] M. Hascoet, and M. Florentz, "Influence of nitrates on biological phosphorus removal from wastewater," in Water S. A. vol. 11 No. 1, 1985, pp. $1-8$.

[14] J. Hernandez, L. E. de-Bashan, and Y. Bashan, "Starvation enhances phosphorus removal from wastewater by the microalga chlorella spp. co-immobilized with azospirillum brasilense," in Enzyme and Microbial Technology vol. 38 No.1-2, 2006, pp. 190-198.

[15] H. Monclús, J. Sipma, G. Ferrero, I. Rodriguez-Roda, and J. Comas, "Biological nutrient removal in an mbr treating municipal wastewater with special focus on biological phosphorus removal," in Bioresource Technology vol. 101 No.11, 2010, pp. 3984-3991.

[16] C. Jia, Y. Dai, J. Chang, C. Wu, Z. Wu, and W. Liang, “Adsorption characteristics of used brick for phosphorus removal from phosphate solution, " in Desalination and Water Treatment vol. 51 No. 28-30, 2013, pp. 5886-5891.

[17] M. Coma, M. Verawaty, M. Pijuan, Z. Yuan, and P. L. Bond, "Enhancing aerobic granulation for biological nutrient removal from domestic wastewater," in Bioresource Technology 103 No.1, 2012, pp. 101-108.

[18] G. K. Morse, S. W. Brett, J. A. Guy, and J. N. Lester, (1998) "Review: Phosphorus removal and recovery technologies," in Science of the Total Environment vol. 212 No.1, 1998 pp. 69-81.

[19] H. Brix, and C. A. Arias, "The use of vertical flow constructed wetlands for on-site treatment of domestic wastewater: new danish guidelines," in Ecological Engineering vol. 25 No. 5, 2005, pp. 491500 .

[20] J. Chen, Y. Cai, M. Clark, Y. Yu, "Equilibrium and kinetic studies of phosphate removal from solution onto a hydrothermally modified oyster shell material," in PLoS ONE vol. 8 No. 4: e60243, 2013, doi:10.1371/journal.pone. 0060243.

[21] L. Fondu, I. Decoster, I., I. De Bo, and S. Van Hulle, "Phosphate sorption capacities of different substrates in view of application in water treatment systems for ponds," IWA Montreal, Canada 2010 [IWA World Water Congress $7^{\text {th }}$ Proceedings].

[22] M. Özacar, "Adsorption of phosphate from aqueous solution onto alunite," in Chemosphere vol. 51 No. 4, 2003, pp. 321-327

[23] M. Özacar, "Contact time optimization of two-stage batch adsorber design using second-order kinetic model for the adsorption of phosphate onto alunite," in Journal of Hazardous Materials vol. 137 No. 1, 2006, pp. 218-225.

[24] K. Cheung, and T. Venkitachalam, 'Improving phosphate removal of sand infiltration system using alkaline fly ash," in Chemosphere vol. 41 No. 1, 2000, pp. 243-249.

[25] Y. Li, C. Liu, Z. Luan, X. Peng, C. Zhu, Z. Chen, Z. Zhang, J. Fan, and Z. Jia, "Phosphate removal from aqueous solutions using raw and activated red mud and fly ash," in Journal of Hazardous Materials vol. 137 No.1, 2006, pp. 374-383.

[26] Z. Brogowski, and G. Renman, "Characterization of opoka as a basis for its use in wastewater treatment," in Polish Journal of Environmental Studies vol. 13 No. 1, 2004, pp.15-20.

[27] L. D. Hylander, and G. Simán, "Plant availability of phosphorus sorbed to potential wastewater treatment materials," in Biology and Fertility of Soils vol. 34 No.1, 2001, pp. 42-48.

[28] L. Johansson, and J. P. Gustafsson, "Phosphate removal using blast furnace slags and opoka-mechanisms," in Water Research vol. 34 No. 1, 2000, pp. 259-265.

[29] J. P. Gustafsson, A. Renman, G. Renman, and K. Poll, "Phosphate removal by mineral-based sorbents used in filters for small-scale wastewater treatment," in Water Research vol. 42 No. 1, 2008, pp. 189-197. 
[30] C. Vohla, R. Alas, K. Nurk, S. Baatz, and Ü. Mander, "Dynamics of phosphorus, nitrogen and carbon removal in a horizontal subsurface flow constructed wetland," in Science of the Total Environment vol. 380 No1-3, 2007, pp. 66-74.

[31] N. Farahbakhshazad, and G. M. Morrison, "Phosphorus removal in a vertical upflow constructed wetland system," in Water Science and Technology vol. 48 No.5, 2003, pp. 43 -50.

[32] C. Vohla, E. Põldvere, A. Noorvee, V. Kuusemets, and Ü. Mander, "Alternative filter media for phosphorous removal in a horizontal subsurface flow constructed wetland," in Journal of Environmental Science and Health - Part A Toxic/Hazardous Substances and Environmental Engineering vol. 40 No. 6-7, 2005, pp. 1251-1264.

[33] T. Zhu, T. Mæhlum, P. D. Jenssen, and T. Krogstad, "Phosphorus sorption characteristics of a light-weight aggregate," in Water Science and Technology vol. 48 No.5, 2003, pp. $93-100$.

[34] Johansson, L. "The use of LECA (light expanded clay aggregrates) for the removal of phosphorus from wastewater," in Water Science and Technology vol. 35 No. 5, 1997, pp. 87 -93.

[35] J. Littler, J. N. Geroni, D. J. Sapsford, R., Coulton, and A. J. Griffiths, "Mechanisms of phosphorus removal by cement-bound ochre pellets," in Chemosphere vol. 90 No. 4, 2013, pp. 1533-1538.

[36] W. Huang, S. Wang, Z. Zhu, L. Li, X. Yao, V. Rudolph, and F. Haghseresht, "Phosphate removal from wastewater using red mud," in Journal of Hazardous Materials vol. 158 No.1, 2008, pp. 35-42.

[37] P. J. M. R. Dable, Y. J. Adjoumani, B. Yao, and G. Ado, "Wastewater dephosphorization using crude clays," in International Journal of Environmental Science and Technology vol. 5 No.1, 2008, pp. 35-42.

[38] S. Hauge, R. Østerberg, K. Bjorvatn, and K. Selvig, "Defluoridation of drinking water with pottery: effect of firing temperature," in European Journal of Oral Sciences vol. 102 No 6, 1994, pp. 329-333.

[39] M. Mohapatra, S. Anand, B. K. Mishra, D. E. Giles, and P. Singh, "Review of fluoride removal from drinking water," in Journal of Environmental Management vol. 91 No 1, 2009, pp. 67-77.

[40] A. Tikariha, and O. Sahu, "Low cost adsorbent for defluoridation of water," in International Journal of Environmental Monitoring and Analysis vol. 1 No 2, 2013, pp. 65-70.

[41] N. Priyantha, and A. Bandaranayaka, (2011) "Investigation of Kinetics of Cr(VI)-fired Brick Clay Interaction," in Journal of Hazardous Materials vol. 188 No 1-3, 2011, pp. 193-197.

[42] J. Rivera-Utrilla, I. Baustista-Toledo, M.A. Ferro-Garcia, and Moreno-Castilla, "Activated carbon surface modification by adsorption of bacteria and their effect on aqueous lead adsorption," in Journal of chemical Technology and Biotechnology vol. 79, 2001, pp. 1209-1215.

[43] S. Moharami and M. Jalali, "removal of phosphorus from aqueous solution by Iranian natural adsorbents," in Chemical engineering Journal vol. 223, 2013, pp. 328-339.

[44] Y. Yan, X. Sun, F. Ma, J. Li, J. Shen, W. Han, X. Liu, and L. Wang, "Removal of phosphate from etching wastewater by calcined alkaline residue: Batch and column studies,' in Journal of the Taiwan Institute of Chemical Engineers vol. 45 No.4, 2014, pp. 1709-1716.

[45] T.E. Köse, and B. Kıvanç, "Adsorption of phosphate from aqueous solutions using calcined waste eggshell," in Chemical Engineering Journal vol. 178, 2011, pp. 34-39.

[46] R.A. Ogutu, K.A.Williams, G.M. Pierzynski, "Phosphate sorption of calcined materials used as components of soilless root media characterized in laboratory studies," in HortScience vol. 44 No.2, 2009, pp.431-437.

[47] H.J. Bray, S.A.T. Redfem, S.M. Clark, "The Kinetics of dehydration in Ca-montmorillonite: An in situ X-ray diffraction study," in Mineral Magazine vol. 62, 1998, 647-656.

[48] H. Noyan, M. Önal, and Y. Sarikaya, "The effect of heating on the surface area, porosity and surface acidity of a bentonite," in Clays and Clay Minerals vol. 54 No.3, 2006, pp. 375-381.

[49] A.K. Yadav, C. P. Kaushik, A. K. Haritash, A. Kansal, and N. Rani, "Defluoridation of groundwater using brick powder as an adsorbent," in Journal of Hazardous Materials vol. 128 No.2-3, 2006, pp. 289293.

[50] A. Dey, R. Singh, and M. K. Purkait, "Cobalt ferrite nanoparticles aggregated schwertmannite: a novel adsorbent for the efficient removal of arsenic," in Journal of Water Process Engineering 3, 2014, pp. 1-9.
[51] S. Yang, Y. Zhao, D. Ding, Y. Wang, C. Feng, Z. Lei, Y. Yang, and Z. Zhang, "An electrochemically modified novel tablet porous material developed as adsorbent for phosphate removal from aqueous solution," in Chemical Engineering Journal vol. 220, 2013, pp. 367374.

[52] P.R Rout, P. Bhunia, and R. R. Dash, "Modeling isotherms, kinetics and understanding the mechanism of phosphate adsorption onto a solid waste: Ground burnt patties," in Journal of Environmental Chemical Engineering vol. 2 No. 3, 2014, pp. 1331-1342.

[53] S. Tian, S., P. Jiang, P. Ning, and Y. Su, "Enhanced adsorption removal of phosphate from water by mixed lanthanum/aluminum pillared montmorillonite," in Chemical Engineering Journal vol. 151 No. 1-3, 2009, 141-148.

[54] Petrik Laboratories, Inc in Taylor, Y, Removal of Phosphate from wastewater using Bricks. Unpublished Masters thesis. Coventry: Coventry University, 2005.

[55] Taylor, Y, Removal of Phosphate from wastewater using Bricks. Unpublished Masters thesis. Coventry: Coventry University, 2005.

[56] I. Mall, S. Upadhyay, and Y. Sharma, "A review on economical treatment of wastewaters and effluents by adsorption," in International Journal of Environmental Studies vol. 51 No.2, 1996, pp. 77-124.

[57] S. Ismadji, F.E Soetaredjo, A. Ayucitra, Clay materials for environmental remediation. Springer, 2015.

[58] S. Mnasri, N. Hamdi, N. Frini-Srasra, and E. Srasra, "Acid-base properties of pillared interlayered clays with single and mixed $\mathrm{zr}-\mathrm{al}$ oxide pillars prepared from tunisian-interstratified illite-smectite," in Arabian Journal of Chemistry 2014 in press.

[59] S. Arfaoui, N. Hamdi, N. Frini-Srasra, E. Srasra, "Determination of point of zero charge of PILCS with single and mixed oxide pillars prepared from Tunisian-smectite," in Geochemistry International vol. 50, 2012, 447-454.

[60] M.H Kalavathy, T. Karthikeyan, S. Rajgopal, L.R. Miranda, "Kinetic and isotherm studies of $\mathrm{Cu}$ (II) adsorption onto $\mathrm{H}_{3} \mathrm{PO}_{4}$-activated rubber wood sawdust," in Journal of Colloid Interface Science vol. 292 No.2, 2005, pp. 354-362.

[61] A.O.Ifelebuegu, Removal of steroid hormones by activated carbon adsorption- kinetics and thermodynamic studies," in Journal of environmental Protection vol. 3, 2012, pp. 469-475.

[62] S. Langergren, "About the theory of so-called adsorption of soluble subtances," in Kungliga Svenska Vetenskapsakademiens handlingar vol. 24 No. 4, 1898, pp. 1-39.

[63] H. Zhou, Z. Jiang, and S. Wei, (2013) "A novel absorbent of nano-fe loaded biomass char and its enhanced adsorption capacity for phosphate in water," in Journal of Chemistry vol. 2013.

[64] N. Y. Mezenner, and X. Bensmaili, "Kinetics and thermodynamic study of phosphate adsorption on iron hydroxide-eggshell waste," in Chemical Engineering Journal vol. 147 No. 2-3, 2009, pp. 87-96.

[65] R. Subha, and C. Namasivayam, "Kinetics and isotherm studies for the adsorption of phenol using low cost micro porous $\mathrm{ZnCl}_{3}$ activated coir pith carbon." in Journal of environmental engineering and science vol. 8 No. 1, 2013, pp. 23-35.

[66] W. Huang, D. Li, Z. Liu, Q. Tao, Y. Zhu, J. Yang, and Y. Zhang, "Kinetics, isotherm, thermodynamic, and adsorption mechanism studies of la(oh)3-modified exfoliated vermiculites as highly efficient phosphate adsorbents," in Chemical Engineering Journal vol. 236, 2014, pp. 191-201.

[67] W. Huang, J. Chen, F., He, J. Tang, D. Li, Y. Zhu, and Y. Zhang, (2015) "Effective phosphate adsorption by zr/al-pillared montmorillonite: insight into equilibrium, kinetics and thermodynamics," in Applied Clay Science vol. 104, 2015, pp. 252260 .

About Author (s):

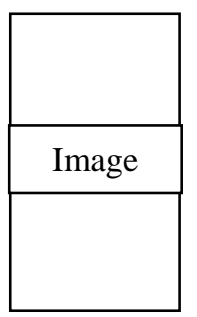

Uduakobong Edet is a doctoral research student with the School of Energy, Construction and Environment, Coventry University UK. 